\title{
An Empirical Analysis of the Market Structure and Market Performance of the Commercial Banks in City $\mathrm{L}$
}

\author{
WANG Ya \\ School of Economics and Management, Lanzhou Jiaotong University \\ Lanzhou, Gansu Province, 730070
}

\begin{abstract}
Since the city $\mathrm{L}$ is a transportation junction in the northwest of China, the development of the commercial banks in city $L$ cannot be overlooked. Taken the commercial banks of city $L$ as an object of research, this paper adopts data envelopment analysis (DEA) to calculate the relationship among market structure, market behaviour effect-operating efficiency and market performance of the commercial banks in city $L$. It can be concluded that the market structure of the commercial banks in city $L$ has a small influence on the market performance, and the operating efficiency is a major factor that determines the performance. The effectiveness of efficient structure hypothesis for the market of the commercial banks in city $L$ is proved. Finally, according to the analysis results, the corresponding strategies and suggestions are proposed.
\end{abstract}

Keywords-Commercial bank; Market structure; Operating efficiency; Market performance

\section{OVERVIEW OF THE MARKET STRUCTURE THEORY}

\section{A. The Concept of Market Structure and Its Determinants}

The market structure refers to the interconnectivity and characteristics of enterprises within a certain industry, reflecting the relationship of the competition and monopoly of enterprises in the industry. There are four basic types of market structure: perfect competition market, perfect monopoly market, oligopoly market, and monopolistic competition market.

The determinants of market structure include market concentration, product differentiation, barriers to entry and to exit, and growth rate of demand, etc. Market concentration is an index that reflects the degree of concentration of a particular industry, and it reflects the controlling degree of few large enterprises to the market. Product differentiation is product personalisation in which enterprises distinguishes their products from the products of other enterprises in the same industry so as to affect the purchasers' preference and to increase the market share. The barrier to entry represents the difficulty level for newcomers entering the market, reflecting the competitive relationship between existing enterprises and newcomers in the industry. The market demand rate refers to the ratio of the mount of certain product or service bought by the purchasers within a certain period and at a certain price.

About the Author: WANG Ya (1981- ), female, lecturer from Lanzhou of

Gansu Province, mainly engaged in finance and financial management.
Products that remain a high market demand rate in a long term are more likely to form market monopoly as well as monopolistic competition market structure. Among them, market concentration is the most significant determinants. The higher the degree of market concentration, the stronger the control of large enterprises and the monopoly power of the market; vice versa. This paper takes the market concentration as a representative index to analyse the market structure of commercial banks in city $\mathrm{L}$.

\section{B. Measuring Indexes of Market Concentration}

This article adopts the concentration rate of industry and Herfindahl-Hirschman index to jointly analyse the market structure of the commercial banks in city $\mathrm{L}$.

(1)The concentration rate of industry (referred to as CRn index for short), indicates the proportion of the several largest enterprises in a certain industry, in terms of total assets and production and sales volume. The formula is:

$$
C R_{n}=\sum_{i=1}^{n} X_{i} / \sum_{i=1}^{N} X_{i}
$$

$C R_{n}$ : the concentration rate of industry of the several largest enterprises in the industry; $X_{i}$ : the related values of the enterprise ranked $i$-th in the industry.

$\mathrm{n}$ is the total number of the several largest enterprises in the industry; $\mathrm{N}$ is the total number of all enterprises in the industry.

The disadvantage of the index of $C R_{n}$ is that it mainly reflects the overall scale and conditions of several large enterprises, but cannot show the scale of other enterprises. Therefore, it is one-sided, and cannot fully reflect the market structure of the entire industry.

(2)Herfindahl-Hirschman Index Based on the shortcomings of using the concentration rate of industry to measure market concentration, scholars have introduced the Herfindahl-Hirschman index (referred as HHI index for short), 
to measure the level of industry concentration in a more accurate and comprehensive manner. The formula is:

$$
H H I=\sum_{i=1}^{n}\left(X_{i} / X\right)^{2}=\sum_{i=1}^{n} S_{i}^{2}
$$

Wherein, $X$ is the overall market scale of a certain industry, $X_{i}$ is the scale of the enterprise ranked i-th in the industry, $S_{i}$ is the market share of the enterprise ranked i, and $\mathrm{n}$ is the total number of enterprises in the industry.
There is a positive relationship between HHI and market concentration. The higher the HHI, the higher the degrees of concentration and monopoly are. The calculated results of HHI can accurately reflect the market concentration, and are especially sensitive to the changes in market share of the largest enterprises. The specific classification criteria based on HHI are shown as follows:

TABLE I CLASSIFICATION CRITERIA OF MARKET STRUCTURE BASED ON HHI

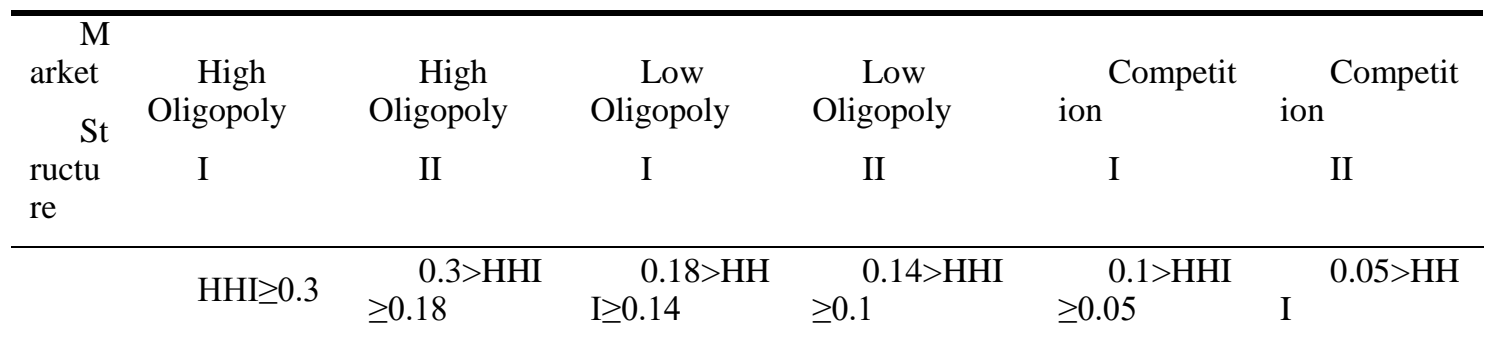

Source of material: SU Dongshui. Industrial economics (the second edition) [M].Beijing: Higher Education Press, 2005.12.8

\section{EMPIRICAL ANALYSIS OF THE MARKET STRUCTURE OF THE COMMERCIAL BANKS IN CITY L}

Currently, the Commercial banks in city L mainly include: Bank of China, China Construction Bank, Agricultural Bank of China, Industrial and Commercial Bank of China, Gansu Bank, Lanzhou Bank, Postal Savings Bank, China Merchants Bank, Bank of Communications, China CITIC Bank, Shanghai Pudong Development Bank, China Zheshang Bank and Rural Cooperation Bank, etc. Due to the completeness of data acquired, the data of 12 banks in 2012-2016, including their deposits, loans, and assets, are used herein as the research object. Moreover, 12 commercial banks are divided into four major categories: 1. large commercial banks (Agricultural Bank of China, China Construction Bank, Industrial and Commercial Bank of China, Bank of China and Bank of Communications); 2. local commercial banks (Lanzhou Bank, Gansu Bank, and Rural Cooperative Bank); 3. small and medium-sized commercial banks (including China CITIC Bank, China Merchants Bank, Shanghai Pudong Development
Bank). 4. Postal Savings Bank. The market share and loan concentration can be calculated based on these.

\section{A. Market Share of Assets}

Table 1 shows the changes in the assets shares of commercial banks in city L: 1. large commercial banks are fully reinforced and their assets account for more than half of the entire banking market. However, as can be seen from the data, their share of assets shows a clear downward trend. The most representative bank is Industrial and Commercial Bank of China, which fall by $6 \%$ in six years. 2. Local commercial banks have grown rapidly. Their asset share as a whole is on the rise. Rural Cooperative Banks has increased their assets by $10 \%$ from 2012 to 2016 due to their wide and deep coverage. 3. The performance of small and medium-sized banks is stable. In the past six years, their share of assets has increased slightly, but it does not account for a large proportion. Shanghai Pudong Development Bank and China Merchants Bank are the main forces for small and medium-sized commercial banks gaining market share.

It can thus be seen that although the share of assets of large commercial banks in the entire banking market is declining year by year, their share of assets is still a major component of the commercial banking market. 
TABLE II List OF CHANGES IN ASSET MARKET SHARE OF 12 TyPES OF BANKS IN City L UNIT (\%)

\begin{tabular}{|c|c|c|c|c|c|}
\hline Name of Bank & $\begin{array}{l}\text { Year of } \\
2012\end{array}$ & $\begin{array}{l}\text { Year of } \\
2013\end{array}$ & $\begin{array}{l}\text { Year of } \\
2014\end{array}$ & $\begin{array}{l}\text { Year of } \\
2015\end{array}$ & $\begin{array}{l}\text { Year of } \\
2016\end{array}$ \\
\hline Industrial and Commercial Bank of China & 22.3 & 20.3 & 19.6 & 18.2 & 16.6 \\
\hline Agricultural Bank of China & 19.2 & 19.0 & 18.7 & 17.8 & 16.7 \\
\hline Bank of China & 7.1 & 7.4 & 7.8 & 7.1 & 7.5 \\
\hline China Construction Bank & 17.4 & 17.0 & 17.5 & 17.8 & 17.1 \\
\hline Bank of Communications & 4.3 & 4.2 & 4.1 & 3.7 & 3.6 \\
\hline Total for Large Commercial Banks & 70.3 & 67.9 & 67.7 & 64.6 & 61.5 \\
\hline
\end{tabular}
China Merchants Bank
5.0
4.8
4.9
4.1
3.9

Shanghai Pudong Development Bank

4.9

4.1

4.7

5.0

5.1

China CITIC Bank

3.1

3.7

3.5

3.8

3.9

\begin{tabular}{lccccc}
\hline $\begin{array}{c}\text { Total for Small and Medium-sized Commercial } \\
\text { Banks }\end{array}$ & 13.0 & 12.6 & 13.1 & 12.9 & 12.9 \\
\hline Gansu Bank & 5.3 & 5.6 & 6.1 & 6.3 & 6.6 \\
Lanzhou Bank & 7.0 & 7.8 & 7.4 & 7.9 & 8.0 \\
$\quad \begin{array}{l}\text { Rural Credit Cooperative } \\
\text { (Rural Cooperative Bank) }\end{array}$ & 10.7 & 12.6 & 13.1 & 13.9 & 21.8 \\
\hline & & & & 36.4 \\
Total for Local Commercial Banks & 17.7 & 26.0 & 26.6 & 28.1 & 3.7 \\
\hline Postal Savings Bank & 3.1 & 3.5 & 3.6 & 3.8 &
\end{tabular}

\section{B. Market Share of Deposits}

Table 2 shows the changes in the market share of deposits in the commercial banks of L: 1. Large commercial banks control more than half of the entire market, but a year-by-year clear declining trend is shown. Among them, the declining of ICBC is about $4.8 \%$, which is the most significant; 2 . The deposits share of small and medium-sized and local commercial banks shows an upward trend year by year. The deposits market share of local commercial banks is slightly higher than that of small and medium-sized banks. The development of small and medium-sized banks is rapid, and 
the increase in their share of deposits is much higher than that of local commercial banks.

It can be seen from this that the predominant competitive advantage of large commercial banks is being weakened slowly. The local commercial banks have a steady and increasing share of the deposits, though their overall growth rate is relatively low. The small and medium-sized commercial banks expand rapidly, participating in market competition with a relatively high growth rate, and they are competing for the market share of deposits.

TABLE III LIST OF CHANGES IN DEPOSIT MARKET SHARE OF 12 TyPES OF BANKS IN City L UNIT (\%)

\begin{tabular}{|c|c|c|c|c|c|}
\hline Name of Bank & $\begin{array}{l}\text { Year of } \\
2012\end{array}$ & $\begin{array}{l}\text { Year of } \\
2013\end{array}$ & $\begin{array}{l}\text { Year of } \\
2014\end{array}$ & $\begin{array}{l}\text { Year of } \\
2015\end{array}$ & $\begin{array}{l}\text { Year of } \\
2016\end{array}$ \\
\hline Industrial and Commercial Bank of China & 17.8 & 15.8 & 15.6 & 15.8 & 13.0 \\
\hline Agricultural Bank of China & 10.7 & 10.8 & 10.2 & 9.6 & 8.4 \\
\hline Bank of China & 7.5 & 8.2 & 8.9 & 8.4 & 8.9 \\
\hline China Construction Bank & 15.6 & 15.0 & 15.9 & 16.5 & 16.3 \\
\hline Bank of Communications & 8.8 & 8.9 & 8.8 & 8.6 & 8.7 \\
\hline Total for Large Commercial Banks & 56.4 & 56.7 & 59.4 & 58.9 & 55.3 \\
\hline China Merchants Bank & 5.4 & 5.0 & 7.7 & 8.0 & 8.5 \\
\hline Shanghai Pudong Development Bank & 3.1 & 3.0 & 3.3 & 4.3 & 4.4 \\
\hline China CITIC Bank & 1.0 & 1.9 & 2.1 & 2.0 & 2.4 \\
\hline $\begin{array}{l}\text { Total for Small and Medium-sized Commercial } \\
\text { Banks }\end{array}$ & 9.5 & 9.9 & 11.1 & 14.3 & 15.3 \\
\hline
\end{tabular}

Lanzhou Bank

Rural Cooperative Bank

Gansu Bank

Total for Local Commercial Banks

Postal Savings Bank

3.18

2.73

2.15

11.8

11.3

11.5

. Market Share of Loans

Table 3 shows the changes in the market share of loans in city $\mathrm{L}$, in which the changes that are similar to those of the market share of deposits are shown. Large commercial banks control more than half of the market in the market of loans, but the market share is significantly declining. It is shown that the advantages of large commercial banks are gradually weakening. At the same time, the numbers of small and medium-sized and local commercial banks gradually increase. 
The market share of local commercial banks is slightly lower than the market share of small and medium-sized commercial banks, but the increase of the former is larger.

TABLE IV List of Changes IN LOAN MARKet Share of 12 Types of BANKS IN City L Unit (\%)

Name of Bank 2012

Year of 2013

Year of 2014

Year of 2015

Year of

Year of 2016

Industrial and Commercial Bank of China

Agricultural Bank of China

Bank of China

China Construction Bank

Bank of Communications

Total for Large Commercial Banks

China Merchants Bank

Shanghai Pudong Development Bank

China CITIC Bank

Total for Small and Medium-sized Commercial Banks

Lanzhou Bank

10.5

6.5

6.7

15.9

8.4

9.4

9.3

9.6

64.3

58.5

58.4

54.4
8.6

2.6

1.8

13.0

13.7

7.6

7.1

7.5
3.3

1.7

12.2

14.9

8.0

6.7

8.4
9.9

51.1

13.0
Rural Cooperative Bank

23.7

28.4

29.7

29.6

30.4

0.02

Postal Savings Bank

\section{.}

In conclusion, the monopoly of large commercial banks is weakening, while the local and small and medium-sized banks are developing rapidly. The competition of the commercial banking market is become more and more fierce. 


\section{MEASURING OF THE MARKET CONCENTRATION RATE OF THE COMMERCIAL BANKS IN CITY L}

\section{A. Measuring of Absolute Concentration Rate}

Table 4 reflects the absolute concentration rate of commercial banks in city L, which are analysed from three aspects: assets, deposits, and loans. It can be seen from the table that, in terms of deposits, large commercial banks are no longer ranked in the top five lastingly. One local commercial bank ranks in the top three. Its CR4 value is different from the former by $2 \%$, and it differs by about $8 \%$ from the fourth. From the data analysis, we can see that the market concentration of assets of banks in city $\mathrm{L}$ is higher than that of deposits of banks in city L. With regional advantages, the local commercial banks bring great pressure to large commercial banks and have become their strong competitors. The monopoly degree of large commercial banks is continuously declining, and their predominant advantages are gradually weakening. Fierce competition is presented in the entire market. In terms of loans, the concentration rate range from $61 \%$ to $72 \%$, and decline continuously by about $10 \%$ during the five years. Among the top four banks in terms of loans, there are three large banks, one local commercial bank which ranked third with a share of loans that is not significantly different from the top two. The competition is evident.

TABLE V CR4 INDEX FOR CONCENTRATION OF COMMERCIAL BANKING INDUSTRY IN CITY L

\begin{tabular}{llllll}
\hline Item & 2012 & 2013 & 2014 & 2015 & 2016 \\
\hline Assets & 76.6 & 75.8 & 75.8 & 73.8 & 72.1 \\
Deposits & 65.4 & 65.1 & 64.5 & 64.4 & 60.6 \\
Loans & 71.9 & 69.2 & 70.1 & 66.9 & 61.1 \\
\hline
\end{tabular}

\section{B. Measuring of Relative Concentration Rate}

Table 5 reflects the relative concentration rate of commercial banks in city L. It can be seen from the table that the HHI indexes of commercial banks in city L from 2012 to 2016 have declined to varying degrees. Wherein, the declining in the HHI index of loans is most significant, reaching 3 percentage points. It can be seen that the market structure of the commercial banks in city L is gradually shifting from low oligopoly to low oligopoly II. As the strength of small and medium-sized banks and local commercial banks continues to increase, fierce competition has been formed among commercial banks in city L.

From the index of $\mathrm{N}$ (Table 6), it can be seen that various commercial banks in city $\mathrm{L}$ with similar assets, deposits, and loans have increased in different degrees from 2012 to 2016. One of the reasons for the change in market structure behind the data is that large commercial banks have carried out a series of reforms in the corporate system. While another reason is that the small and medium-sized local commercial banks grow rapidly. As of November 2016, there are 15 commercial banks in city L. Among them, Shanghai Pudong Development Bank, China CITIC Bank, Zhejiang Commercial Bank, and Hua Xia Bank have advantages in capital, technology, talents, and services. Local banks, such as Gansu Bank and Lanzhou Bank, continue to grow and expand under the support of policies. The competition among the commercial banking market in city $\mathrm{L}$ is become increasingly fierce, and the monopolistic advantages of large commercial banks have disappeared.

TABLE VI RELATIVE CONCENTRATION RATE OF COMMERCIAL BANKING INDUSTRY IN City L UNiT (\%)

\begin{tabular}{llllll}
\hline HHI & 2012 & 2013 & 2014 & 2015 & 2016 \\
\hline Assets & 0.2 & 0.2 & 0.2 & 0.2 & 0.2 \\
Deposits & 0.1 & 0.1 & 0.1 & 0.1 & 0.1 \\
Loans & 0.2 & 0.2 & 0.2 & 0.1 & 0.1 \\
\hline
\end{tabular}

TABLE VII Relative CONCENTRATION RATE OF COMMERCIAL BANKS IN CITY L (INDEX OF N)

\begin{tabular}{l|ccccc}
\hline Index of N & 2012 & 2013 & 2014 & 2015 & 2016 \\
\hline Assets & 6.2 & 6.3 & 6.3 & 6.6 & 6.8 \\
Deposits & 7.0 & 7.2 & 7.3 & 7.3 & 7.8 \\
Loans & 6.4 & 6.7 & 6.6 & 7.0 & 8.1 \\
\hline
\end{tabular}

To sum up, the market structure of commercial banks in city $\mathrm{L}$ is changing from the higher oligopoly market structures to the lower oligopoly market structures. Small and medium-sized and local commercial banks have taken advantages of flexible business strategies and policy support, etc. to continuously challenge large commercial banks and to 
share the market share of the large commercial banks. The monopoly of the large commercial banks will be gradually disintegrated. Competition among banks is bound to become more and more intense. Especially after 2008, through the rapid expansion of small and medium-sized commercial banks, such as Shanghai Pudong Development Bank and China CITIC Bank, it can be clearly seen that the market structure of commercial banks in city $\mathrm{L}$ is changing toward monopolistic competition. Such change has brought great influence to the development of the financial industry in city L.
IV. EMPIRICAL ANALYSIS OF THE MARKET STRUCTURE AND MARKET PERFORMANCE OF THE COMMERCIAL BANKS IN CITY L

\section{A. Choosing of Variables and Establishment of Models}

This paper empirically analyses the market structure and operating efficiency of commercial banks in city L, studies their impact on market performance. DEA is adopted as a measurement method to establish a multiple regression model. Wherein, the independent variables are the market share of deposits and loans, market concentration rate and operating efficiency and the dependent variable is the return rate of assets. With the SPSS software, the data of 12 banks in five years are substituted into the efficiency level model for regression analysis. The regression model is established as follows:

$$
Y=0.034+0.023 X_{1}+0.041 X_{2}-0.289 X_{3}+0.011 X_{4}+\xi
$$

In the formula $3.1, \mathrm{Y}$ is market performance and is represented by return on assets (ROA); X1 is the market share of deposits of the bank; X2 is the market share of loans of the bank; X3 is the market concentration rate of loans; X4 is the operating efficiency of the bank; $\xi$ is other control variable related to the market; $\gamma_{0}$ is constant; and $\gamma_{1}, \gamma_{2}, \gamma_{3}$ and $\gamma_{4}$ are the regression coefficients for each variable.

The return on assets (ROA) can reflect the utilization efficiency of the assets of commercial banks, and is the most prominent indicator of their performance. Therefore, it is used as a dependent variable. Moreover, compared to other factors, market shares of deposits and loans have a stronger correlation with the performance level. Therefore, they are used as the explanatory variables $\mathrm{X} 1$ and $\mathrm{X} 2$. In addition, since the size of loans depends to some extent on the size of deposits and the main source of bank income is loan interest, the market concentration rate of loans serves as the explanatory variable $\mathrm{X} 3$. The above three explanatory variables all reflect their impact on the performance level of banks from the perspective of market structure. The explanatory variable $\mathrm{X} 4$ is the index of operating efficiency, which reflects the operating effects of banks. According to the efficient structure hypothesis, efficiency determines market performance. By examining the relationship between the performance and efficiency of commercial banks, resources can be rationally allocated and a better investment output model can be established, so as to reduce costs and obtain excess profits. Therefore, establishment of an efficiency level model can help verify the effectiveness of the efficient structure hypothesis for the commercial banking market in city $\mathrm{L}$.

The results of data calculation of banks show the relationship between the market shares of deposits and loans, the market share of loans, the market concentration rate of loans, market operating efficiency, and the performance level of banks. The significance coefficient of deposits market share is 0.023 , and the significance coefficient of loans market share is 0.041 , and the significance coefficient of operating efficiency is 0.011 . These show a strong correlation between them and the market performance, that is, there is a significant positive correlation between these factors and the performance level of banks. At the same time, the significance coefficient of the market concentration rate of loans is -0.289 , showing that its correlation in the efficiency level model is not strong.

\section{B. Causes Analysis}

(1)There was a significant positive correlation between the market shares of deposits and loans, market operating efficiency, and performance level of banks. The reason is that the deposit and loan business is the main business of banks. From the perspective of accounting, deposits are the banks' liabilities (i.e. banks need to pay for them), loans are the banks' assets (i.e. they are the banks' source of income), and the difference between deposits and loans is the main component of the banks' profits. However, the amount of deposits and loans need to be within a reasonable range. If the amount exceeds the range, the correlation level will be reduced.

(2)The main reasons for the negative correlation of the loan market concentration rate include: First, the utilization efficiencies of deposits of banks are varied greatly. The rural credit cooperatives and postal savings banks have a wide business segment, and the market share of deposits is relatively large. However, the development of their loan business is not synchronized with the deposit business and is relatively slow, resulting in underutilized deposits and low return on assets. Second, L City is in the underdeveloped western region. Compared with developed regions, its effective social capital scale is relatively limited, which also restricts the scale of $\mathrm{L}$ city commercial bank loan requirements. In addition, the access threshold of loans is too high, and some loan demander cannot reach the requirements or cannot provide corresponding loan collateral, etc. Thereby, the allocation scope of bank assets is narrowed, causing the low return on assets of banks. 


\section{CONCLUSIONS AND SUGGESTIONS}

(1)The market scale of commercial banks in city L has expanded dramatically. The small and medium-sized commercial banks with stronger strength, such as Shanghai Pudong Development Bank and Zheshang Bank, are developing faster. For the large state-owned commercial banks, the market structure will completely change. The state-owned commercial banks lag far behind the small and medium-sized commercial banks in terms of operating system, operating principle, product update, and service awareness. If they do not change the development mode, they will lose more and more market share.

(2)The development of the financial industry cannot be separated from the support of industrial policies. Finance is the key to active the economy of a city. The growing vitality of the banking market requires the government to increase support for the small and medium-sized and local enterprises as well as to give full play to the prominent function of government in serving small and medium-sized enterprises and emerging industries.

(3)The homogeneity of the market of commercial banks in city $\mathrm{L}$ does not mean that banks do not need innovation. Innovation is the key to the rapid development of any enterprise. After interest rate liberalization, the interest income of banks will definitely be reduced. The main source of profits for banks is currently concentrated on traditional business of assets and liabilities. With the continuous deepening of the interest rate liberalization reform, competition will become increasingly concentrated on the new market. This requires banks that make profits mainly by interest rates to change their operating principles and develop new products to obtain new profits.

\section{REFERENCES}

[1] QI Meidong. Study on the market structure of Chinese bank industry [M]. Beijing: Economic Science Press. 2008.

[2] LIU Yong, SHANG Wencheng, MU Hongsheng. Study on the organizations of Chinese bank industry [M]. Shanghai: Shanghai University of Finance and Economics Press, 2009.

[3] MA Zhanxin. Data envelopment analysis and methods [M]. Beijing: Science Press, 2010.

[4] WEI Yu, WANG Li. Study on the efficiency of Chinese commercial banks: non-parametric analysis [J]. Journal of Financial Research, 2000 (3).

[5] TAN Zhengxun.Study on the structure and system of Chinese bank industry [M]. Beijing: China Finance Press. 2009.

[6] GAO Wei. Study on the structural approach for organizations in bank industry [J]. Economic Affairs, 2009 (6).

[7] HUANG Juan, LI Hui. Analysis on the market structure of the U.S. commercial banking industry [J]. International Finance Research, 2010 (7).S. 